\title{
HOW CAN DEVELOPING ACADEMIC NEEDS OF DELTA ENGINEERING STUDENT, AFFECTS ON THEIR COMMUNICATION AND WRITING SKILLS
}

\author{
Dr. Abdulrahman Elsayed AlAdl \\ English TEFL Lecturer \\ Delta University for Science and Technology
}

\begin{abstract}
:
The purpose of this paper is to identify English language needs of engineering students in Delta University, that affect on their technical writing and communication skills. The study is based on needs analysis approach to detect the main academic needs of students, that might lead to developing their communication and writing skills. A needs analysis through survey questionnaire was done on two different groups: students group and engineering professors group. The currents research paper made use of two questionnaires for the data collection, involved 500 students, and 20 engineering professors in the faculty of Engineering at Delta University. The research tools was applied during the academic year 20142015. A quantitative and qualitative analyses were performed for the collected data.

Results of the research paper show that engineering students need sufficient linguistic competence in English, and specific technical skills related to language studying that need to be included into the courses particularly writing and communication skills.

Based on the attained results, it is recommended that continuous English session throughout extended semesters should be designed for students to improve their communicative skills through interactive tasks. Moreover, assigning positive activities accordingly would help to achieve the goals and objectives of the courses.
\end{abstract}

Key words: Needs analysis, technical writings kills, learner autonomy, feedback.

$$
\begin{aligned}
& \text { ملخدف ورقة البحث المطروحة إلى تحديد } \\
& \text { الاحتياجات الأكاديمية المتعلقة بتعلم اللغة } \\
& \text { الإنجليزية لدي طلاب كلية الهندسة في جامعة } \\
& \text { الالتا، والتي تؤثر على تتمية مهاراتهم فى لإيلي }
\end{aligned}
$$

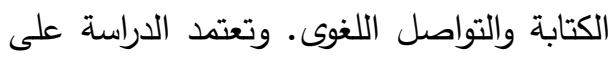

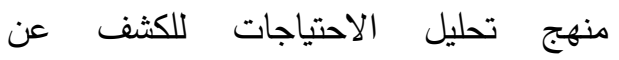

$$
\begin{aligned}
& \text { الاحتياجات الأكاديمية الرئيسية للطلاب، والتي } \\
& \text { قد تئدي إلى تطوير مهارات الاتصال والكتابة. } \\
& \text { وقد تم تحليل الاحتياجات من خلال الاستبيان } \\
& \text { المطبق على مجموعتين بحثيتين مختلفتين: }
\end{aligned}
$$

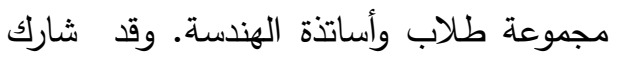

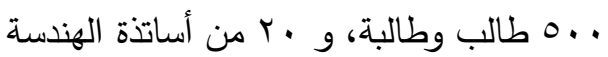

$$
\begin{aligned}
& \text { في كلية الهندسة بجامعة الدلتا. } \\
& \text { و تم تطبيق أدوات البحث خلال العام الدراسي }
\end{aligned}
$$

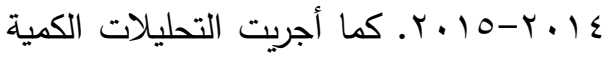

$$
\begin{aligned}
& \text { والنوعية للبيانات التي تم جمعها. } \\
& \text { أظهرت نتائج البحث أن طلاب الهندسة بحاجة } \\
& \text { إلى الكفاءة اللغوية باللغة الإنجليزية، ومهارات } \\
& \text { فنية معينة تتعلق باللغة والتي تطلب إدراجها } \\
& \text { في مناهج اللغة الإنجليزية بكلية الهندسة }
\end{aligned}
$$




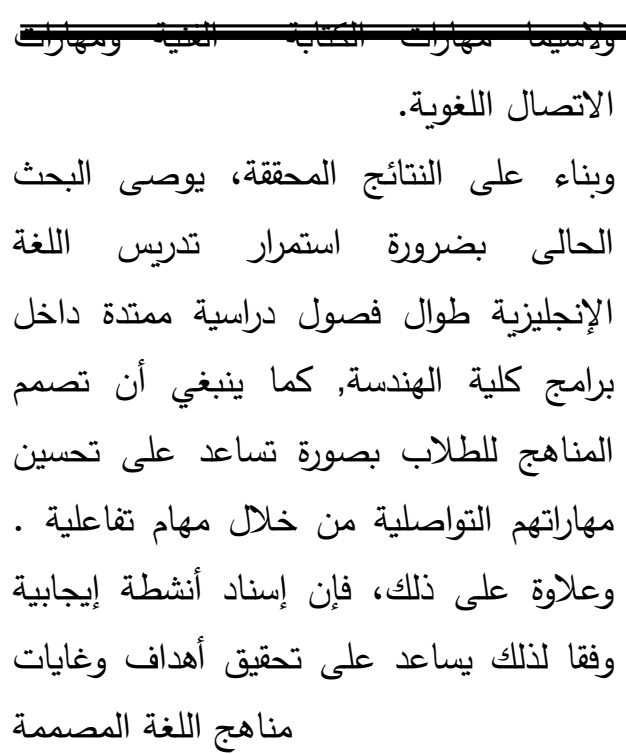

Introduction:

English communication ability for engineers has become as important as their major related abilities. Engineers all around the world would find themselves use English for some aspects of their jobs. English is used in most international organizations and publications in engineering field and most engineers would find disadvantages in their professional terms.

For engineering domain, students have to achieve enough competence in English language to do well in writing and communication tasks, such as writing technical reports, projects, training reports, utilizing well structured sentences, discuss various topic in fluent English, communicate with people, do satisfied presentations, (Basturkmen and AlHuneidi, 1996; Hyland, 1997; Abdul Aziz, 2004; Siti Hanim and Ismie Roha, 2005; Ostler et al., 2008).

(Gilabert, \& Long, 2005) indicated that task based NAs have gained attention. Needs analysis was introduced into language teaching through the English for Specific Purposes (ESP) movement. Hutchinson and Waters (1987) define ESP course design and materials development in which all decisions as to context and method are based on learners' reason for learning" (p.19). "By the 1980s, in many parts of the world a "needs-based philosophy" emerged in language teaching, particularly in relation to ESP and vocationally oriented program design" (Brindley, 1984 as cited in Richards, 2001).

Literature of engineering studies reported that English courses are essential for engineering students. There are many studies confirmed the importance of English language in the academic and professional environment of engineering students (Pendergrass et al., 2001; Pritchard \& Nasr, 2004; Joesba \& Ardeo, 2005; Sidek et al., 2006; Hui, 2007; Venkatraman \& Prema, 2007).

The study of Pendergrass et al. (2001) reported that English is the main tool in engineering studying, and therefore "integrating English into engineering, science and math courses is an effective way to improve the performance of engineering students in oral and written communication" (p. 1).

Moreover, Pritchard \& Nasr (2004) asserted that "English is of distinct effectiveness for engineering students because it is the principal international language of science and is looked upon as an effective means for enabling those students to become familiar with academic contexts in English".

A study of Joesba \& Ardeo (2005) reported that as English has become the official language for science and technological fields, therefore engineering students have to face this fact while they are students, since books, papers, handbooks, journals, etc. written in English are included in their reading lists, and after graduation, because one of their most valuable resources will be English at the labour market. 
confirmed the major role of English confirmed the major role of English all. Various studies undertake the academic needs of engineering students based on needs analysis approach.

The study of Zoghoul \& Hussein (1985) conducted the language academic needs of college stage students from various domains, including natural sciences, engineering, medical sciences, economics, administrative sciences, and arts and humanities. It investigated the expectation of both students and lecturers. Results fulfilled from this study reflected extensive use of English as announced by both students and lecturers. Moreover, results confirmed that the students evaluated their language abilities in more positive ways, whereas lecturers gave a more logic evaluation of the students' skills.

In conclusion, all of the previous research reported that the large number of engineering graduates were limited users of English, particularly submitting technical papers and face to face communication. Research data also agreed on the most significant language skills that considered the most important ones for an expected engineer. In addition to reading and listening skills, studying technical documents and face to face communication are attributed to be the essential language tools. The current research paper claims the attitude towards improving the academic needs for students. Therefore relevant changes in English syllabi for engineering should be taken into consideration.

\section{Statement of the problem}

The analysis of the students' English courses' results of every academic semester indicate a high failure rate that is found to persist among the Engineering students. This has also contributed to their bad performance in their specialized courses. The English language courses actually need to ensure their success in the academic context or specialized field. The current English language courses only expose them to the four major skills generally. They face difficulties in coping with these courses as the faculties also require the students to have other relevant skills such as presentation or public communication skills, report writing or product report skills and other skills that are applicable in their respective programs.

This raises the issue of suitability of the courses as far as the students are concerned since generally there is no specific course that meet the demands of a specific program. Therefore it is important to consider the program needs to ensure the students' success in the academic setting. Another issue is whether these courses adequately prepare the students to function according to their specializations.

This shows the weaknesses of English Language courses in helping the students to acquire the language skills needed by the faculty. The study concludes that relevant actions should be taken as to ensure the needs of the students are fulfilled and they can perform effectively in the program and future career.

\section{Research Questions}

The current research paper tries to answer the following questions:

- What are the academic needs that may affect on developing communication and writing skills of engineering students?

- What are the main weakness points of engineering students in writing and communication skills?

- Does the English course in Delta engineering faculty meet students' academic needs for writing and communication skills?

\section{Significance}

The significance of the current paper stems from the following factors: 
1.Investionate stents' problems with writing and communication skills, by detecting their views, needs and ways for developing. This may led to have a good sight for planning ESP syllabus in engineering college.

2. Addressing the main gaps between students and their English courses and subsequently design a needs evaluated questionnaire to identify these needs which may improve their language main skills.

3. The analysis for English syllabi may present sufficient assessment that could help for implying the relevant shifts for preparing the engineering contexts that meet students' needs and expectations.

4. Results may be useful for students', lecturers and syllabi designers in order to identify the main problems and gaps that prevent enhancing students' performance in English in their required academic and professional fields.

\section{Limitations of the Study}

The current paper is limited to literature that related to need analysis and theories of improving English language skills for engineering students. The method also is limited to questionnaires as tools for the data collection

The sample of students and lecturers were chosen as per random sampling to cover all categories of the engineering faculty. The findings of the paper are based on the ground situations prevailing in the faculty of engineering of Delta university.

Method

The design of this paper is descriptive non-experimental and it employs the Needs Analysis approach. The information was collected through two questionnaires. (Appendix 3 \& Appendix 4)

The items in them were based on communication and writing sub-skills. Six items were designed in the questionnaire in order to identify students' attitude language, while 9 items were to investigate their attitude of communication sub-skills and ten items for writing subskills.

\section{The Participants}

The questionnaires was distributed to engineering students, English lecturers, moreover engineering lecturers and professors of faculty of Engineering, Delta university in Egypt. A total of 500 students and 20 lecturers participated in the questionnaires. Their responses were subjected to descriptive analysis using the SPSS software.

\section{Students' Questionnaire}

It composed of a total 26 question, moreover blanks for students' personal data such as: the semester they belonged to, their major specification of study, their language prior knowledge, the area they belonged to, etc. (Appendix-3)

The instruction of questionnaire is written in a clear simple language, and telling students what to do with every section

The attained data of this survey was used for achieving various main aims. The major aim of the questionnaire was to investigate the academic needs that may develop students' performance in writing and communication skills. In order to achieve this major aim, the questionnaire followed these procedures:

- Firstly, it tried to investigate the English prior knowledge of students and thereby the gaps in the existing syllabi and other related topics, in classroom settings (points 1-2-3-18-19).

- Secondly, it tried to identify the existing shortage of students' academic needs in English writing sub-skills regarding to the frequency of preferred needs and the frequency in which it is applied and achieved in their faculty (items 5-10, 2023).

- Finally, it aimed to elicit information concerning the shortage in 
the frequency of preferred needs and the frequency in which it is applied and achieved in their faculty (items 11-17, 24-25).

- The last point question No. 26 was an open ended question. "From your opinion, what is the best way English to be taught in your faculty?" The data collected from this question is qualitative and descriptive data.

\section{Teachers' Questionnaire}

The aim of This questionnaire was to collect both quantitative and qualitative data concerning the studying practices that were being followed among lecturers of engineering faculty. The objectives of the questionnaire were to elicit data regarding the existing syllabi and how far it is being put into application and then to examine different needs of language in engineering context regarding communication and writing skills. (Appendix-4)

The first part is formed of ten selected needs. Lecturers were asked to express their ideas and concepts to assess the degree of importance of these needs from their view point. They were asked to mark their views on a Likert scale of 1 . Strongly agree, 2. Agree and 3. Disagree

The second part was based on five different (Yes or No type) statements where lecturers were asked to express their ideas. Q. No. (1-5).

The third part was formed of one open ended question 'List the main needs of students in the faculty of Engineering, in your opinion, in studying English for Engineering contexts. lecturers were requested to express their ideas and attitude below each question.

\section{Administration of the Research Instruments}

The questionnaires were administered by the researcher himself $A$ letter from the Head of the Department of the researcher seeking permission to conduct field work was addressed to the dean of the faculty, oresenting the on of the details of the research design. It was administered in the academic year of 2014-2015. The teachers' questionnaire was presented to the professors and lecturers handling classes of engineering basic science.

\section{Validity of the Research Instruments}

Content validity for the questionnaire instruments was attained through a review by a panel of experts. The panel of experts contained 7 figures of TEFL and ESP professors. They were requested to examine the clarity and suitability of the questionnaires (see Appendix 1), intended for both teachers and students.

\section{Reliability of the Research Instruments}

Students' questionnaire was made up of 26 items. The first 25 items were intended to assess students' response to certain issues related to overall language skills development and performance in writing and communication skills in particular. Item 26, the last item, was an opened question regarding students' own choice of English teaching approaches that they would like to be available in their faculty. These items, along with the items in the teachers' questionnaire, were checked for their clarity and suitability for inclusion in the questionnaires by the panel of experts mentioned above.

The reliability statistics of the items were tested through Cronbach's alpha. The Cronbach's alpha value has been mentioned against each item for better interpretation. The reliability coefficient of the Students' Questionnaire was found to be 0.87 . The reliability coefficient of the Teachers' Questionnaire was found to be 0.84 .

\section{Data Analysis}

The first part of the students' questionnaire was designed to investigate a needs analysis of the current English course of Delta engineering faculty in Egypt. This part was mainly focusing on 
the_course_features_and_stents'-attitude towards it. The other 14 items of this section were developed based on subskills. Six items were included in order to capture the attitude of students' towards writing sub-skills while 8 items were to capture their attitude towards communication sub-skills. The scoring of the part is based on summating all the items to get a raw score. The collected data was analysed using the descriptive measures for frequencies and percentages.

Part two is formed of certain questions to investigate students' academic needs, related to their English writing and communication sub skills. The collected data was analysed using the descriptive This part measures for frequencies and percentages.

The last part of the questionnaire was an open-ended question focusing on students' attitude on how they believed English to be taught in their faculty. Qualitative method is used to analyse data for this particular part.

There are also 3 parts in the teachers' questionnaire. The First part is formed of certain questions to investigate teachers' attitude towards the required enhancement in the current English teaching practices being followed in the classrooms. In this part a lower score refers to agreement, whereas a higher score refers to disagreement. The purpose of the second part is to appreciate the general needs would aid in English language teaching in classrooms. The response from the participants comes in the form of Yes/No. the last part is formed to recognize the teachers' attitude towards students' needs in learning writing and communication skills.

\section{Research results}

This part presents the paper results on needs analysis conducted through questionnaires, among students and teachers of engineering faculty, Delta University. Independent variables related

\section{esign, academic related needs in language} design, academic related needs in language learning context were taken into consideration. These variables were selected for data analysis which has been described in detail. The responses of students' questionnaire (both quantitative and qualitative) are calculated on SPSS 17.0 software. The teachers' questionnaire also collected both quantitative and qualitative data. The findings relating to the research questions are discussed in detail. The quantitative data analysis is followed by the qualitative data analysis of both students' and teachers' questionnaire. (Appendices 3 and 4 ).

\section{Results of the students Questionnaire \\ - Students' response to the first Research Question}

- What are the academic needs that may affect on developing communication and writing skills of engineering students?

The academic needs were based on needs for students of identifying previous knowledge of English, guidance and motivation, need of learner autonomy, studying language within lab activities, productive evaluation etc. In order of priority, as mentioned by the students, their needs come as the following:

- English Language lab should be learned throughout intensive lab sessions.

Above $90 \%$ of students agreed with this item. The data show that they recognize the importance of lab courses and were in favour of learning English skills throughout it.

- Need of Freedom and Options in

Doing writing Assignments and

drafts.

More than $70 \%$ of students confirmed their need to write in a free way with continuous and constructive feedback.

the Academic needs, which have been counted below are arranged in order of the 
availability and the rate of students' satisfaction of it

- Relevant and continuous practices in writing reports, proposals and other technical papers $(68 \%$ of students reporting dissatisfaction)

- Need for extra practices to share in peer tasks and leadership, team approaches. $\quad(62 \%$ of students reporting dissatisfaction).

- Need for authentic texts, learning tools that arouse students' motivation in English lab sessions $(55 \%$ of students expressing dissatisfaction).

- Need for participating and practicing activities delivered in language lab (46\% of students expressing dissatisfaction).

- Need for reading technical documents for acquiring new terms, idioms and scientific vocabulary ( $82 \%$ of students expressing dissatisfaction)

- Learning technical Writing sub skills such as designing titles, covers, abstracts tables and graphs (80\% of students expressing dissatisfaction).

Students' expectations regarding guidance in drafting project related documents, understanding documents and reports to gain technical terms, acquisition of team approaches skills and creativity skills etc. were found to be the most vital ones.

\section{Students' response to the second Research Question}

What are the main weakness points of engineering students in writing and communication skills?

The majority of the students asserted that they had many problems with writing tasks. The most weakness point was writing correct and well structured sentences $(78 \%)$, followed by using proper words (69\%), then improving and organizing their writing $(60 \%)$. The last writing sub-skill with the least weakness as reflected by the students was combining proper sentences in paragraphs $(48 \%)$, linking paragraphs in an essay (46\%).

Engineering students' attitude towards their communication weakness, the data reflects that they suffer using correct grammatical language (75\%), speaking fluent English (70\%), using various vocabulary and expressions (65\%) in addition to speaking in trust way $(58 \%)$. The students, on the other hand, reported that they have fewer troubles with participating in discussion (43\%). communicating with others (42\%), providing ideas and supporting their opinions (47.5), and talking clear and loud language $(49 \%)$.

\section{Students' response of the third}

Research Question

- Does the English course in Delta engineering faculty meet students' academic needs for writing and communication skills?

The data for this question were collected out of the last qualitative point in students' questionnaire. The required response from students was about their wishes of how they think English to be learnt in their faculty. And to what extent their academic needs had been met in English course.

The following data of students required needs as reflected of their response.

- Students' personal improvement $(52 \%)$ of students confirmed that they need English courses to help them developing their personality.

- Technical writing skills $(47 \%)$ of students expressed their need to reinforce skills of writing technical engineering papers skills such as designing tables, charts, graphs and preparing for projects and proposals.

- Interactive and dynamic studying environment - $(59.5 \%)$ of students asserted that they need more assist from their faculty and the administrators to achieve this item. 
Consultation participating - $(58.7 \%)$ of students
reported that they wanted more help from their faculty on this aspect.

- Evaluation system- (64\%) of students expressed their need for better assessment patterns.

- Continuous and positive feedback$(52 \%)$ of students reported that they need continuous feedback from their lecturers.

Results of the Teachers' Questionnaire

As in students' questionnaire, the quantitative data analysis in the teachers' questionnaire is focused on qualitative data analysis based upon the three research questions regarding course design and students' academic needs and how far are they met in the language learning context to improve their writing and communication skills.

\section{Teachers' Views of the First \\ Research Question}

- What are the main academic needs of the engineering students that may affect on developing their communication and writing skills?

The academic needs as reported by lecturers as attained from their responses and attitude are presented in order as follows:

- The need for interactive process among ESP experts and designers of engineering syllabi.

- The need for intensive and constructive training programs for engineering lecturers and continuous feedback workshops.

- There is need for the extension and increasing allotted time for English courses through further semesters in engineering learning programs.

Teachers' Views of the Second Research Question

- What are the main weakness points of engineering students in writing and communication skills? questions were captured out of the list of communication and writing sub-skills (Appendix2), which is evaluated by the panel of juries (Appendix1). This list are agreed to be the most weakness points that face engineering students.

All teachers agreed that the students had problems with all writing sub-skills . The biggest problem was using suitable words for writing tasks (95\%), followed by writing correct sentences (94\%), and combining logic paragraphs in an essay $(81 \%)$. The top three problems of communication skills as reported by teachers, were using correct language (90\%), using vocabulary and expressions in proper situations $(88 \%)$ and talking fluent language $(86 \%)$.

- Teachers' Views of the Third Research Question

- Does the English course in Delta engineering faculty meet students' academic needs for writing and communication skills?

The collected data of lecturers responses towards the third research question is presented, as per their order of preference:

- $\quad$ Continuous language practicing should be reinforced throughout the courses of engineering programs.

Assign and design relevant tasks to improve positive English skills related to students' writing and communication skills.

Enhancing suitable English labs, that involving well- equipped software and communicative tools, that enable students to practice and improve their fundamental assigned skills.

The allotted time for technical writing skills should be extended to let students practice alls steps of writing process like preparing then writing first draft and to make use of 
continuous feedback to submit the

final desirable drafts.

- $\quad$ Arousing students motivation to attend and participate positively in English language classes. The lecturers reported that this is the most serious problem of the faculty of engineering as a private college. Lecturers should face this point by creating innovative methods that activate students and focusing their interesting to attend English classes, not only for getting high scores, but for gaining sufficient improvement in language skills.

- $\quad$ Revising the evaluation process to meet students' needs and motivate them. There is need for distributing the total marks throughout the semester and covering both theoretical and practical aspects. Students' also should be encouraged to search with avoiding the repeated and static questions of examinations.

\section{Discussions, Conclusions}

and

\section{Recommendations \\ Discussions}

In this part the results are compared with the findings of other studies in the literature and are analyzed according to the research objectives. Based on the results and discussions, the conclusions have been drawn and recommendations given at the end. The current paper was initially conceived with three basic objectives in mind:

- To investigate students' main problems with learning communication and writing skills and identify the academic needs of students to improve their performance.

- To examine the existing English courses currently taught in the faculty of engineering of Delta University and investigate how far it meets students' writing and communicative needs. to the objectives of the current research paper are discussed to provide a clear idea of the need for undertaking such a study.

Different studies on the importance on needs analysis in ESP curriculum have already been conducted. The findings of these studies have focused on needs analysis based on either learner analysis or task analysis (e.g. Hutchinson \& Waters, 1987; Nunan,1988a; Nunan,1988b;Nunan, 1995; Strevens,1997; Dudley Evans and St. John,1998; Richterich,1983;Ongsakul, 1984; Wittayapirak and Preechapanit, 1992; Michael Long,2005). The learner and the task become the two most critical factors while designing questionnaires and interviews for needs analysis survey, as per these researchers. The present paper additionally focuses on the goals, contents and resources and materials provided in the existing syllabus and puts emphasis on the writing and communicative needs in a learner-centered curriculum to enable students for real life challenges in language contexts.

Lack of communication skills and lack of English language proficiency has been a major concern in many studies conducted (Inyoung Shin, 2008; Rayan 2007; Pawanchik, 2006).The need of writing skills has been emphasized in studies conducted by (e.g. Jackson et.al. 2006; Pritchard, \& Nasr,2004; Tong, 2003) The need to develop oral and written communication skills and other workspecific communication skills such as informal discussions, public speeches and interviews etc. have been the major focus on studies conducted by (Tong, 2003; Splitt,1993; Curry, Sherry and Tunney, 2003; and Kwok, 2004).

\section{Conclusion}

The results of the study report that engineering students need sufficient linguistic competence in English, and specific technical skills related to language 
studving that need to be included into the courses particularly writing and communication skills.

The following conclusions were drawn from the results

And the main theoretical summaries of related literature:

- The importance of communicative practices. The resulted of collected data showed that communicative activities should be redesign to develop students performance. It also showed that this aim has not been achieved totally.

- Evaluation system should be revised to meet students' prior knowledge and language background. Students' language learning abilities and academic needs should be also taken into consideration in using assessment tools.

- Communication activities and writing assignments should be performed in sufficient language lab sessions. Teachers should provide students with enough time to practice freely and give them the relevant constructive feedback.

- The results show that students are in urgent need of extra specific skills that related to language competency, such as personality improvement, interview training skills, communicative activities etc.

- Teachers should create dynamic studying environment. Students must feel that they participate in the learning process in certain aspects like selecting materials, designing lesson plans and suitable worksheets and assignments. This may promote students to express of their strengths and weaknesses

Students expressed that they need to involve technology related activities like e- mails, online discussions, power point presentations, video conferencing, and use of internet. Therefore, the current English syllabi for engineering needs_to_improve_a_setofoneric_skills along with technical skills forming the part of graduating engineers' academic development.

\section{Recommendations}

This study has reached to the following conclusion, based on the results.

- English course assigned for engineering students should include tasks that improve dynamic skills like teamwork, creativity and interview skills. Students should participate in Interactive sessions and several practices with more communicative tasks. Continuous feedback is the major role of teachers.

- English lab activities are so vital for students, so the urgent need for designing relevant practices for students. They should have the opportunity to write reports drafts, design presentations, share peer communicative activities etc.

- Feedback process is so important. Students require continuous assessment that led them for achieving improvement. So evaluation system of English courses should be revised to meet students' needs.

- It is recommended that other researchers conduct additional needs analysis studies to find out the English language needs of students in different schooling stages. In addition, the researcher recommends other researchers to conduct needs analysis studies of other subjects also, so that the teaching learning system gets strengthened in the process.

\section{Reference}

1. Abu-Rizaizah, S. (2005). The process of designing an ESP writing course for engineers in a Saudi company. University of Newcastleupon-Tyne ARECLS e-journal. 2 (3). Retrieved October 5, 2011 from http://research.ncl.ac.uk/ARECLS/vo 12_documents/Saeed/saeed.htm 
workplace: An analysis of the communication needs of tourism and banking personnel. Asian EFL Journal, 7(2), 174-194.

3. Basturkmen, H. and Al Huneidi, A. (1996) 'The Language Needs Analysis Project at the College of Petroleum Engineering Kuwait University. ERIC Document.' Retrieved February 5th 2009.

4. Basturkmen, H. (1998). Refining procedures: A needs analysis projects at Kuwait University. English Teaching Forum, 36(4), 2-9.

5. Brindley, G. (1989). The role of needs analysis in adult ESL programme design. In R. K. Johnson (Ed.), The Second Language Curriculum, (pp. 63 - 78). Cambridge: Cambridge University Press.

6. Dudley-Evans, T. and St. John. (1998). Developments in English for specific purposes: A multidisciplinary approach. UK: Cambridge University Press.

7. Gilabert, R. (2005). Evaluating the use of multiple sources and methods in needs analysis: a case study of journalists in the autonomous community of Catalonia (Spain). In M.H. Long (Ed.), Second language needs analysis, (pp. 182-199). Cambridge: Cambridge University Press.

8. Hui, Z. (2007). Teaching technical English to engineering students. Sino-US English teaching, 4 (9).

9. Joesba, M., and Ardeo, G. (2005) Student engineers, ESP courses, and testing with Cloze Tests. ESP World, 2 (10).

10. Long, M. (2005). Methodological issues in learner needs analysis. In

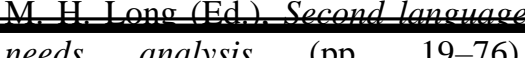

Cambridge: Cambridge University Press.

11.Othman, J. (2005). English language use among EFL learners in Sunway University College. Sunway Academic Journal. English for Specific Purposes World, v.8, issue 23.

12.Pendergrass, N., Kowalczyk, R., Dowd, J., \& Laoulache, R. (2001). Improving first year engineering education. Journal of Engineering Education.

13.Pritchard, M \& Nasr, A. (2004) Improving reading performance among Egyptian engineering students: Principles and practices. English for Specific Purposes 23, 425-445.

14.Richards, J (2001) Curriculum Development in Language Teaching. Cambridge: Cambridge University Press.

15.Sasidharan, Priya(2012) "A NeedsBased Approach to Teaching and Learning of English for Engineering Purposes" Ph D thesis, National Institute Of Technology, India

16.Strevens, P. (1997). ESP after Twenty Years: A Reappraisal. In M.L.Tickoo (ed.) ESP: State of the art (pp.1-13). Singapore, SEAMEO Regional Centre.

17.Zughoul, M. \& Hussein, R. (1985). English for higher education in the Arab world: A case study of needs analysis at Yarmouk University. The ESP Journal, 4, 133- 152. 